\title{
Nuclear DNA content in 20 species of Siluriformes (Teleostei: Ostariophysi) from the Neotropical region
}

\author{
Paulo César Fenerich, Fausto Foresti and Claudio Oliveira \\ Universidade Estadual Paulista, Instituto de Biociências, Departamento de Morfologia, Botucatu, \\ SP, Brazil.
}

\begin{abstract}
In the present study, 20 species of Siluriformes fish were analyzed in order to determine their nuclear DNA content and compare these data with their diploid number. In addition, the extension and importance of the changes that occurred during the process of diversification in the group of Neotropical freshwater catfish were investigated. The only species studied of the family Doradidae, Rhinodoras d'orbignyi $(2 n=58)$, presented $3.46 \pm 0.13$ pg of DNA. Among the species of the family Heptapteridae, the values of nuclear DNA content and the diploid numbers ranged from $1.13 \pm 0.09 \mathrm{pg}$ of DNA in Pimelodella sp. $(2 n=46)$ to $2.38 \pm 0.07 \mathrm{pg}$ of DNA in Imparfinis mirini $(2 \mathrm{n}=58)$. The family Loricariidae showed the widest variation in diploid number and nuclear DNA content values, ranging from $2 n=52$ and $3.96 \pm 0.22 \mathrm{pg}$ of DNA in Liposarcus anisitsi to $2 \mathrm{n}=76$ and $4.90 \pm 0.12 \mathrm{pg}$ of DNA in Hypostomus sp. 4 . In this group, two local samples of Pimelodus maculatus (Pimelodidae) were analyzed, and both exhibited $2 \mathrm{n}=56$, but different nuclear DNA content values $(2.68 \pm 0.22 \mathrm{pg}$ and $2.82 \pm 0.20 \mathrm{pg}$, respectively). Among the Pseudopimelodidae species analyzed, Pseudopimelodus mangurus $(2 \mathrm{n}=54)$ showed $2.23 \pm 0.15 \mathrm{pg}$ and Microglanis cottoides $(2 \mathrm{n}=54)$ exhibited $2.50 \pm 0.18 \mathrm{pg}$ of DNA. Two species of Trichomycterus (Trichomycteridae) also presented the same diploid number, $2 \mathrm{n}=54$ chromosomes, but, while the species from the Quinta stream presented a DNA content of $2.62 \pm 0.19 \mathrm{pg}$, in the sample from the Capivara river this value was $2.30 \pm 0.23 \mathrm{pg}$. In the analyzed species, the results showed that the changes in DNA content were frequently not followed by changes in the diploid number. This fact permits to suggest that, in addition to structural chromosome rearrangements, other mechanisms, including deletions, duplications and polyploidy, could be involved in the process of species differentiation in the representatives of the fish order Siluriformes.
\end{abstract}

Key words: nuclear DNA, DNA content, chromosome, fish, evolution.

Received: June 11, 2003; Accepted: March 29, 2004.

\section{Introduction}

The determination of the nuclear DNA content of the cells constitutes an important tool to be used in biological studies and may provide conditions for a better characterization of the species. Comparative studies among species have shown a wide and significant variation of the nuclear DNA content at several taxonomic levels. An intriguing and interesting question risen by studies on the nuclear DNA content of vertebrates concerns the interpretation of the real meaning of the quantitative variability found among the species and the causes that may determine, in some organisms such as fish, the accumulation of considerable amounts of repetitive DNA sequences (Gregory, 2001a and 2001b). The number of studies on nuclear DNA content in fish has increased considerably over the last de-

Send correspondence to F. Foresti. Universidade Estadual Paulista, Instituto de Biociências, Departamento de Morfologia, 18618000 Botucatu, SP, Brazil. E-mail: fforesti @ ibb.unesp.br. cades, especially of those targeted to North American cyprinid and salmonid species, which present extensive intraand inter-specific variations (Gold and Price, 1985; Gold and Amemiya, 1987; Johnson et al., 1987).

During the last four decades, the Neotropical fish fauna has been the object of only a few studies about nuclear DNA content (Hinegardner, 1968; Hinegardner and Rosen, 1972). More recently, other studies on nuclear DNA content in Neotropical species were conducted by Oliveira et al. $(1992,1993 \mathrm{a}, 1993 \mathrm{~b})$ in different species of Callichthyidae and by Carvalho et al. $(1998,2002)$ in fish species of the order Characiformes. Among the Siluriformes, a considerable diversity of karyotypes, determined by differences in diploid numbers and chromosome formulae, has been found (Oliveira and Gosztonyi, 2000), indicating that this group may constitute an interesting model for the study of the mechanisms involved in the process of speciation in fish. However, for Neotropical fish of the order Siluriformes, only a few studies on nuclear DNA 
content are available and actually involve the data collected for no more than about 37 species (Carvalho et al., 1998). Nuclear DNA content values, associated to karyotypic information, are considered to be good indicators of the evolutionary process that occurs in Neotropical fish (Carvalho et al., 1998, 2002). Thus, the objective of the present study was to analyze and compare information about the nuclear DNA content and the diploid number in 20 species of Siluriformes fish, in order to contribute to a better understanding of the diversification process that occurred in this group.

\section{Material and Methods}

Twenty fish species of the order Siluriformes, collected in rivers of different hydrographic systems in the State of São Paulo, Brazil, were used. Table 1 shows the taxonomic classification of the species, collection sites, and the number and sex of the specimens analyzed. Different species that could not be positively identified were assigned as "sp.", and when more than one unidentified species were present in a genus, the different species were sequentially numbered. After processing, all specimens were fixed and stored at the fish collection of Laboratório de Biologia e Genética de Peixes, Instituto de Biociências, UNESP, Botucatu (SP), Brazil.

Mitotic chromosome preparations were obtained from kidney and gill cells, using the air-drying technique described by Foresti et al. (1993). The individual relative nuclear DNA content was determined according to the technique described by Gold and Price (1985), with some minor modifications. Three slides were used for each individual. Blood was collected by caudal puncture and smeared near the frosted end of the slides. Blood smears from chicken, common carp, and rainbow trout served as standard references for DNA quantification. The absorbance values of the fish nuclei from each slide were standardized as a percentage of the mean absorbance value of the three controls. To express the DNA amount in picograms (pg), the standardized data were multiplied by the known values of standard species $(2.5 \mathrm{pg}, 3.4 \mathrm{pg}$, and $5.5 \mathrm{pg}$, respectively, according to Tiersch et al., 1989). Chicken blood was obtained from a Hampshire male. Rainbow trout and common carp blood samples were obtained from domestic stocks. The slides were fixed in 9:1 methanol-formaldehyde (37\%) for $20 \mathrm{~min}$, rinsed twice (10 min each) in distilled water, dehydrated in $70 \%$ ethanol $(2 \mathrm{~min})$ and $95 \%$ ethanol ( $2 \mathrm{~min}$ ), and stored desiccated overnight at $4{ }^{\circ} \mathrm{C}$. Then, individual batches of 20 (randomized) slides were hydrolyzed in $1.0 \mathrm{~N} \mathrm{HCl}$ at $60^{\circ} \mathrm{C}$ for $15 \mathrm{~min}$, rinsed briefly in distilled water, and stained with Schiff's reagent (Feulgen stain) for $2 \mathrm{~h}$. Hydrolysis time was empirically determined as the point of maximum absorbance in a hydrolysis curve. Following staining, the slides were rinsed twice (10 min each) in SO2 water and once (10 min) in distilled water, air-dried in the dark, and analyzed. Microdensito- metry analysis was performed under a Zeiss microscope using a 100x oil-immersion objective, and data analysis was based on the OPTIMAS software, version 4.1. For each specimen, nuclei of 30 cells were measured on two slides (15 nuclei per slide). The third slide was kept as a backup. Only the roughly spherical and homogeneously Feulgenstained nuclei found in clear areas of the slide were selected for measurement.

\section{Results and Discussion}

The variation in nuclear DNA content values found for the different species of Siluriformes was very conspicuous, as can be observed in Table 1 . These values were characterized at the intraspecific and interspecific levels in this fish group, confirming observations previously reported by Oliveira et al. (1993b) in representatives of the family Callichthyidae. This fact could be related to the presence of still undetermined species in the analyzed sample. A sample of Hypostomus sp. $3(2 \mathrm{n}=72)$ collected in the Edgardia stream exhibited $3.67 \pm 0.24 \mathrm{pg}$ of DNA, whereas another sample of individuals, from the Paranapanema river, with the same diploid number, showed $4.72 \pm 0.39 \mathrm{pg}$, a difference considered significant.

The only species of Doradidae analyzed, Rhinodoras d'orbignyi, presented $3.46 \pm 0.13$ pg of DNA and a diploid number of $2 \mathrm{n}=58$ chromosomes (Table 1 ). In this group, a similar value was described by Hinegardner and Rosen (1972) in Acanthodoras spinosissimus, a related species, that presented $3.20 \mathrm{pg}$ of DNA per nucleus.

Among the Loricariidae, the study of different species of Hypostomus revealed a great variation of diploid numbers, ranging from $2 n=64$ to $2 n=76$. In this case, the variation does not seem to be directly related to the size of the genome in the different cytotypes (Table 1), since Hypostomus sp. 1 from the Paranapanema river $(2 \mathrm{n}=64)$ presented $3.89 \pm 0.22 \mathrm{pg}$ of DNA, and Hypostomus sp. 3 from the Edgardia stream $(2 \mathrm{n}=72)$ had $3.67 \pm 0.24 \mathrm{pg}$ of DNA (Table 1). Another species of the subfamily Hypostominae, Liposarcus anisitsi, presented $2 \mathrm{n}=52$ and $3.96 \pm 0.22 \mathrm{pg}$ of DNA. However, Neoplecostomus paranensis, a species of the subfamily Neoplecostominae, considered as one of the most primitive species in the family Loricariidae, presented $2 \mathrm{n}=54$ and $2.26 \pm 0.17 \mathrm{pg}$ of DNA (Table 1). Similarly, the species Hisonotus sp. 1 (Hypoptopomatinae) presented $2 \mathrm{n}=54$ and $2.66 \pm 0.12 \mathrm{pg}$ of DNA, and the species Hisonotus sp. 2 presented $2 \mathrm{n}=54$ and $1.78 \pm 0.10 \mathrm{pg}$ of DNA (Table 1). These results suggest that the differences found among the species of this group could be due not only to simple chromosome rearrangement events, but also to the occurrence of changes involving all the genome of the species, with the possible occurrence of polyploidy in the origin of some members of the subfamily Hypostominae.

Extensive variability involving chromosome numbers and karyotypic formulae is considered a characteristic 
Table 1 - Siluriformes fish species analyzed, collection sites, number of individuals analyzed, diploid number (2n), and diploid nuclear DNA content values in picograms (pg)

\begin{tabular}{|c|c|c|c|c|}
\hline Species & Collection sites & Fish analyzed M/F/? & $2 \mathrm{n}$ & Nuclear DNA content (pg) \\
\hline \multicolumn{5}{|l|}{ Doradidae } \\
\hline Rhinodoras d'orbignyi & Paranapanema river, Itatinga & $0 / 2 / 0$ & 58 & $3.46 \pm 0.13$ \\
\hline \multicolumn{5}{|l|}{ Heptapteridae } \\
\hline Cetopsorhamdia iheringi & Quinta stream, Itatinga & $2 / 2 / 0$ & 58 & $1.76 \pm 0.14$ \\
\hline Cetopsorhamdia iheringi & Alambari stream, Botucatu & $0 / 2 / 1$ & 58 & $1.80 \pm 0.12$ \\
\hline Heptapterus longicauda & Quinta stream, Itatinga & $4 / 2 / 0$ & 52 & $2.21 \pm 0.18$ \\
\hline Imparfinis mirini & Alambari stream, Botucatu & $3 / 3 / 0$ & 58 & $1.88 \pm 0.16$ \\
\hline Imparfinis mirini & Capivara river, Botucatu & $3 / 2 / 0$ & 58 & $2.38 \pm 0.07$ \\
\hline Imparfinis mirini & Quinta stream, Itatinga & $0 / 2 / 2$ & 58 & $1.88 \pm 0.10$ \\
\hline Imparfinis mirini & Jacutinga stream, Bofete & $3 / 5 / 0$ & 58 & $2.06 \pm 0.14$ \\
\hline Imparfinis mirini & Edgardia stream, Botucatu & $5 / 3 / 0$ & 58 & $1.99 \pm 0.14$ \\
\hline Pimelodella sp. 1 & Alambari stream, Botucatu & $4 / 1 / 0$ & 46 & $1.13 \pm 0.09$ \\
\hline Pimelodella sp. 2 & Paranapanema river, Itatinga & $1 / 2 / 3$ & 52 & $2.03 \pm 0.13$ \\
\hline Rhamdia hilarii* & Jacutinga stream, Bofete & $4 / 1 / 1$ & $58-61$ & $2.25 \pm 0.18$ \\
\hline Rhamdia hilarii & Paranapanema river, Itatinga & $3 / 1 / 0$ & 58 & $2.00 \pm 0.20$ \\
\hline Rhamdia hilarii & Edgardia stream, Botucatu & $4 / 1 / 0$ & 58 & $1.97 \pm 0.10$ \\
\hline \multicolumn{5}{|l|}{ Loricariidae } \\
\hline Hypostomus sp. 1 & Paranapanema river, Itatinga & $2 / 3 / 0$ & 64 & $3.89 \pm 0.22$ \\
\hline Hypostomus sp. 2 & Alambari stream, Botucatu & $3 / 0 / 1$ & 68 & $4.75 \pm 0.20$ \\
\hline Hypostomus sp. 2 & Jacutinga stream, Bofete & $5 / 1 / 0$ & 68 & $4.02 \pm 0.27$ \\
\hline Hypostomus sp. 3 & Quinta stream, Itatinga & $1 / 2 / 0$ & 72 & $4.32 \pm 0.15$ \\
\hline Hypostomus sp. 3 & Paranapanema river, Itatinga & $4 / 2 / 0$ & 72 & $4.72 \pm 0.39$ \\
\hline Hypostomus sp. 3 & Edgardia stream, Botucatu & $3 / 1 / 0$ & 72 & $3.67 \pm 0.24$ \\
\hline Hypostomus sp. 4 & Paranapanema river, Itatinga & $0 / 1 / 0$ & 76 & $4.90 \pm 0.12$ \\
\hline Hypostomus sp. 4 & Hortelã stream, Botucatu & $4 / 2 / 0$ & 76 & $4.18 \pm 0.27$ \\
\hline Hisonotus sp. 1 & Quinta stream, Itatinga & $2 / 2 / 0$ & 54 & $2.66 \pm 0.12$ \\
\hline Hisonotus sp. 2 & Jacutinga stream, Bofete & $5 / 5 / 0$ & 54 & $1.78 \pm 0.10$ \\
\hline Liposarcus anisitsi & Tietê river, Barra Bonita & $5 / 0 / 0$ & 52 & $3.96 \pm 0.22$ \\
\hline Neoplecostomus paranensis & Hortelã stream, Botucatu & $1 / 0 / 4$ & 54 & $2.26 \pm 0.17$ \\
\hline \multicolumn{5}{|l|}{ Pimelodidae } \\
\hline Pimelodus maculatus & Paranapanema river, Itatinga & $2 / 4 / 4$ & 56 & $2.68 \pm 0.22$ \\
\hline Pimelodus maculatus & Tietê river, Barra Bonita & $1 / 4 / 0$ & 56 & $2.82 \pm 0.20$ \\
\hline \multicolumn{5}{|l|}{ Pseudopimelodidae } \\
\hline Microglanis cottoides & Araquá river, Botucatu & $3 / 4 / 0$ & 54 & $2.50 \pm 0.18$ \\
\hline Pseudopimelodus mangurus & Paranapanema river, Itatinga & $1 / 0 / 0$ & 54 & $2.23 \pm 0.15$ \\
\hline \multicolumn{5}{|l|}{ Trichomycteridae } \\
\hline Trichomycterus sp. & Quinta stream, Itatinga & $2 / 4 / 0$ & 54 & $2.62 \pm 0.19$ \\
\hline Trichomycterus cf. iheringi & Capivara stream, Botucatu & $4 / 1 / 0$ & 54 & $2.30 \pm 0.23$ \\
\hline
\end{tabular}

(*) Species with B chromosomes; M - Male; F - Female; ? - Not sexed.

feature in Siluriformes, mainly among representatives of the families Pimelodidae, Pseudopimelodidae and Heptapteridae. Cytogenetic studies conducted on 33 species belonging to these groups showed diploid numbers that ranged from $2 \mathrm{n}=46$ to $2 \mathrm{n}=60$ chromosomes (Swarça et al., 2000). The analysis of two species of Pimelodella sp. (Heptapteridae) showed that changes in nuclear DNA content seem to be associated with changes in diploid number, as opposed to what occurs in some other species, such as Imparfinis mirini (Heptapteridae) and Pimelodus maculatus (Pimelodidae). As observed by Swarça et al. (2000), the diploid numbers found among the species of the above mentioned families are not homogeneous, suggesting that the karyotypic evolution process that occurred in those families was rather divergent than conservative (Swarça et al., 2000). Our results suggest that, in addition to 
the occurrence of chromosome rearrangements, other mechanisms including changes in DNA content may be involved in the speciation process of these groups. Events involving the fusion of acrocentric chromosomes which resulted in the origin of biarmed chromosomes, through breaks and losses of small DNA segments corresponding to the pericentromeric region of the chromosomes, could determine a substantial loss of genetic material, with consequent changes in the nuclear DNA content of the species (Redi et al., 1990; Slijepcevic, 1998; Caputo et al., 1998). Such cytological events could be identified as being responsible for changes occurred in the genomic structure and, consequently, for the species differentiation in these groups.

The presence of supernumerary chromosomes usually produces a high variation coefficient in DNA content of the species (Carvalho et al., 1998). In the present study, the Rhamdia hilarii specimens collected in the Jacutinga stream presented diploid numbers ranging from $2 \mathrm{n}=58$ to $2 \mathrm{n}=61$ and a nuclear DNA content value of $2.25 \pm 0.18 \mathrm{pg}$ (Table 1), while both the specimens from the Paranapanema river and from the Edgardia stream presented $2 \mathrm{n}=58$ chromosomes and $2.00 \pm 0.20 \mathrm{pg}$ and $1.97 \pm 0.10 \mathrm{pg}$ of DNA, respectively. The differences in nuclear DNA content found in the genus Rhamdia may be due to the presence of one to three supernumerary chromosomes in the population of the Jacutinga stream. A variation in DNA content among individuals, due to the presence of different numbers of supernumerary chromosomes, was also observed by Carvalho et al. (2002) in their study of two populations of Moenkhausia sanctaefilomenae.

The analysis of two species of Trichomycterus (Trichomycteridae) showed that, although both of them presented the same diploid number $2 n=54$, there were conspicuous differences regarding their nuclear DNA content. In the individuals of the sample collected in the Quinta stream, the mean value found was $2.62 \pm 0.19 \mathrm{pg}$ of DNA, whereas in those from the Capivara river it was $2.30 \pm$ $0.23 \mathrm{pg}$ of DNA (Table 1). A similar variation was observed by Carvalho et al. (2002) in two local populations of Astyanax fasciatus, a Characidae species with $2 \mathrm{n}=46$ and $2 \mathrm{n}=48$ chromosomes and $3.50 \pm 0.18$ and $2.75 \pm 0.10 \mathrm{pg}$ of nuclear DNA per cell, respectively. The differences found in the nuclear DNA content of these species seem also to be related with internal changes occurred in the chromosomes, suggesting that the gain or loss of relatively high amounts of DNA may play an important role in the process of speciation and evolution of these organisms, as pointed out by Hinegardner (1976).

The knowledge about intraspecific differences in Tropical fish is still limited. According to Gregory (2001a and 2001b), such differences are implicit in comparisons involving characteristics such as cell size, nucleus size and cell metabolism. Thus, the differences found in the amount of DNA in vertebrate cells could be related to differences in cell size, and changes involving this characteristic during evolution may be related to the different lifestyles of the organisms and to their adaptation to different environments. According to the author, large-sized cells and large amounts of DNA per cell could be related with low metabolic levels and with the capacity of tolerating changes in the composition of the body fluid. Small cells and low DNA content could be characteristics of groups of organisms with high metabolic rates and with precise regulatory processes of the internal metabolism, demonstrating the relationship between the adaptation capacity of those organisms and their degree of specialization (Gregory, 2001a, 2001b).

The analysis performed on different species of Siluriformes fish in the present study showed an extensive interspecific variability in their nuclear DNA content. According to Ohno (1974), modifications in the DNA content of the organisms can normally occur, and several models of gene duplication described in fish were used to explain the great diversity found in genome size among the species. Due to this process, fish might be provided with diverse gene arrays which permit them to occupy different environments. According to the author, the occurrence of gene duplication or polyploidy may have produced a redundancy of some DNA segments. Thus, if the duplication that occurred involved non-transcribed DNA segments, individuals of specific populations could maintain the duplicated segments without affecting the maintenance of the species genome.

The analysis of nuclear DNA content associated with karyotype studies conducted in the present work in species of the order Siluriformes proved to be an important tool in the study of relationships among species, and the data obtained will certainly contribute to a better understanding of the evolutionary history of this group.

\section{Acknowledgments}

The authors thank R. Devidé and M.L. Carvalho for their technical assistance and Dr. V. Dal Pai for allowing the use of the microdensitometer. The chicken blood was provided by Mr. H. Emílio from Biotério Central of UNESP, Botucatu (SP); common carp blood was provided by Mr. J. Batista from CAUNESP, Jaboticabal (SP), and rainbow trout blood was provided by Mr. M.G. Rigolino from Estação Experimental de Salmonicultura, Campos do Jordão (SP). Funds supporting this study were provided by FAPESP, CAPES, CNPq, and FUNDUNESP.

\section{References}

Caputo V, Sorice V, Vitturi R, Magistrelli R and Olmo E (1998) Cytogenetic studies in some species of Scorpaeniformes (Teleostei: Percomorpha). Chrom Res 6:255-62.

Carvalho ML, Oliveira C and Foresti F (1998) Nuclear DNA content of thirty species of Neotropical fishes. Genet Mol Biol 21:47-54. 
Carvalho ML, Oliveira C, Navarrete MC, Froehlich O and Foresti F (2002) Nuclear DNA content determination in Characiformes fish (Teleostei, Ostariophysi) from the Neotropical region. Genet Mol Biol 25:49-55.

Foresti F, Oliveira C and Almeida-Toledo LF (1993) A method for chromosome preparations from large specimens of fishes using in vitro short treatment with colchicine. Experientia 49:810-813.

Gold JR and Amemiya CT (1987) Genome size variation in North American minnows (Cyprinidae). II. Variation among 20 species. Genome 29:481-489.

Gold JR and Price HJ (1985) Genome size variation among North American minnows (Cyprinidae). I. Distribution of the variation in five species. Heredity 54:297-305.

Gregory TR (2001a) Coincidence, coevolution, or causation? DNA content, cell size, and the C-value enigma. Biol Rev 76:65-101.

Gregory TR (2001b) The bigger the C-value, the larger the cell: genome size and red blood cell size in vertebrates. Blood Cells, Molecules, and Diseases 27:830-845.

Hinegardner R (1968) Evolution of cellular DNA content in teleost fishes. Am Nat 102:517-523.

Hinegardner R (1976) Evolution of genome size. In: Ayala FJ (ed) Molecular Evolution. Massachustter, Sinauer, pp 179-199.

Hinegardner R and Rosen DE (1972) Cellular DNA content and evolution of Teleostean fishes. Amer Nat 106:621-644.

Johnson OW, Utter FM and Rabinovitch PS (1987) Interspecies differences in salmonid cellular DNA identified by flow cytometry. Copeia 1987:1001-1009.

Ohno S (1974) Animal cytogenetics. Chordata 1 - Protochordata, Cyclostomata and Pisces. 4. Gebrüder Borntraeger, Berlin, $92 \mathrm{pp}$.
Oliveira C, Almeida-Toledo LF, Mori L and Toledo Filho SA (1992) Extensive chromosomal rearrangements and nuclear DNA content changes in the evolution of the armoured catfish genus Corydoras (Pisces, Siluriformes, Callichthyidae). J. Fish Biol 40:419-431.

Oliveira C, Almeida-Toledo LF, Mori L and Toledo Filho SA (1993a) Cytogenetic and DNA content studies on armoured catfishes of the genus Corydoras (Pisces, Siluriformes, Callichthyidae) from the southeast coast of Brazil. Rev Bras Gen 16:617-629.

Oliveira C, Almeida-Toledo LF, Mori L and Toledo Filho SA (1993b) Cytogenetic and DNA content in six genera of the family Callichthyidae (Pisces, Siluriformes). Caryologia 46:171-188.

Oliveira C and Gosztonyi AE (2000). A cytogenetic study of Diplomystes mesembrinus (Teleostei, Siluriformes, Diplomystidae) with a discussion of chromosome evolution in siluriforms. Caryologia 53:31-37.

Redi CA, Garagna S and Zuccotti M (1990) Robertsonian chromosome formation and fixation: The genomic scenario. Biol J Linnean Soc 41:235-255.

Slijepcevic P (1998) Telomeres and mechanisms of Robertsonian fusion. Chromosoma 107:136-140.

Swarça AC, Caetano-Giuliano L and Dias AL (2000) Cytogenetics of species of the families Pimelodidae and Rhamdiidae (Siluriformes). Gen Mol Biol 23:589-593.

Tiersch TR, Chandler RW, Wachtel SS and Elias S (1989) Reference standards for flow cytometry and application in comparative studies of nuclear DNA content. Cytometry 10:706-710

Associate Editor: Sergio Furtado dos Reis 